\title{
DINAMIKA PERIKANAN TUNA LONG LINE INDONESIA (STUDI KASUS TUNA SIRIP BIRU SELATAN)
}

\section{(FIESHERIES DYNAMICS OF INDONESIA TUNA LONG LINE: CASE STUDY OF THE SOUTHERN BLUEFIN TUNA)}

\author{
Novia Tri Rahmawati1,2, Sugeng Hari Wisudo ${ }^{3}$, Eko Sri Wiyono ${ }^{3}$,Tri Wiji Nurani ${ }^{3}$ \\ ${ }^{1}$ Corresponding author \\ ${ }^{2}$ Ditjen Perikanan Tangkap, Kementerian Kelautan dan Perikanan \\ ${ }^{3}$ Departemen Pemanfaatan Sumberdaya Perikanan \\ Fakultas Perikanan dan Ilmu Kelautan, Institut Pertanian Bogor \\ E-mail: novia_tri@yahoo.co.id
}

\begin{abstract}
As the member of Commission for The Conservation of Southern Bluefin Tuna (CCSBT), Indonesia shall follow the quota measure of SBT fishing that has determined. Therefore, good management and rules were needed for SBT exploitation in Indonesia in order to align with measures and international regulation that has agreed by Indonesia as part of CCSBT. The objectives of this research wereto determine catch composition, productivity of Indonesia tuna longline fisheries especially that doing SBT fishing activity; to estimatesfishing season; and to determine mean size at capture of SBT in Indonesia. Theresult showedthat catch composition of tuna longline has the smallest percentage value for the type of SBT. Trend of SBT production percentage was increase every year in 19 years period. Fishing season of SBT in Indonesia was in Angust to March that assumed same with nursery season of SBT. Mean size at capture of SBT $\left(L_{50 \%}\right)$ was $145 \mathrm{cmFL}$. This size that assumed has feasible to be caught or has beyond spawning period.
\end{abstract}

Keywords: Southern bluefin tuna(SBT), tuna long line

\section{ABSTRAK}

Sebagai anggota Commission for the Conservation of Southern Bluefin Tuna (CCSBT), Indonesia harus mengikuti aturan kuota penangkapan tuna sirip biru selatan (southern bluefin tuna/SBT) yang telah ditetapkan. Untuk itu diperlukan pengaturan dan tata kelola yang baik dalam pemanfaatan SBT di Indonesia agar selaras dengan kaidah dan aturan-aturan internasional yang telah disepakati Indonesia sebagai bagian dari CCSBT. Penelitian ini bertujuan untuk menghitung komposisi hasil tangkapan dan tingkat produktivitas armada tuna long line Indonesia khususnya yang melakukan aktivitas penangkapan SBTmenduga bulan musim penangkapan dan menghitung ukuran rata-rata tertangkap SBT hasil tangkapan tuna long line Indonesia. Hasil penelitian menunjukkan jenis SBT memiliki nilai persentase terkecil dari komposisi hasil tangkapan tuna long line di Indonesia. Namun demikian, tren persentase produksi SBT memiliki kecenderungan meningkat dari tahun ke tahun seiring dengan meningkatnya tren produktivitas tuna long line. Musim penangkapan SBT di Indonesia terjadi pada bulan Agustus-Maret, yang diduga juga merupakan musim pemijahan tuna sirip biru selatan. Ukuran rata-rata tertangkap SBT $\left(\mathrm{L}_{50} \%\right)$ adalah berukuran $145 \mathrm{~cm}$ FL sehingga bisa dikategorikan sudah layak tangkap karena telah melalui fase ikan melakukan pemijahan atau recruitment.

Kata kunci: Tuna sirip biru selatan, tuna long line

\section{PENDAhuluan}

Tuna sirip biru selatan (Thunnus maccoyit)atauyang dikenal dengan sebutan southern bluefin tuna (SBT) adalah jenis tuna besar, bisa berenang dengan cepat, beruaya sangat jauh (highly migratory), dan merupakan jenis ikan pelagis besar. Kawasan perairan selatan Indonesia merupakan jalur migrasi SBT. Tuna sirip biru selatan bagi Indonesia merupakan salah satu jenis tangkapan yang mempunyai nilai eko- nomi tinggi. Ikan SBT sebagian besar diekspor ke Jepang karena adanya permintaan sashimi yang kuat di pasar Jepang.Harga SBT berdasarkan hasil interview diperoleh informasi bahwa ratarata SBT fresh sashimi grade di pasar ekspor berkisar $¥ 1000$ - ¥2500 per kg.

Daerah operasi penangkapan SBT di Indonesia umumnya berada di Wilayah Pengelolaan Perikanan Republik Indonesia (WPP-RI) 573, disekitar perairan Samudera Hindia sebelah Selatan Jawa. Wilayah ini juga merupakan wilayah 
nomor 1 (satu) dari Area Statistical of Catch yang diatur Commission for The Conservation of Southern Bluefin Tuna (CCSBT). Para ahli menduga bahwa wilayah tersebut diduga sebagai wilayah pemijahan (spawning ground)SBT. Penelitian yang dilakukan oleh beberapa ilmuwan seperti Proctor et al, (1995), Yukinawa (1987), Farley dan Davis (1998) menyatakan bahwa sumber daya SBT diduga mempunyai tempat pemijahan (spawning ground) tunggal yaitu antara barat laut Australia dan perairan selatan pulau Jawa.

Pemanfaaan SBT di Indonesia sebagian besar menggunakan alat tangkap tuna long linedengan berbagai ukuran kapal. Umumnya armada penangkapan tersebut berpangkalan di Pelabuhan Benoa Bali dan Pelabuhan Perikanan Samudera Nizam Zachman Jakarta. Armada penangkapan yang berpangkalan di Bali adalah anggota Asosiasi Tuna Long LineIndonesia (ATLI).Armada penangkapan yang berpangkalan di Jakarta umumnya adalah anggota Asosiasi Tuna Indonesia (ASTUIN). Kedua organisasi tersebut mendapat jatah kuota penangkapan SBT yang diberikan oleh CCSBT. Secara administrasi kedua organisasi tersebut harus melakukan pencatatan data dalam pemanfaatan SBT.

Industri perikanan tuna sirip biru selatan, secara global, mengacu pada kuota penangkapan yang telah diatur oleh CCSBT. Commission for the Conservation of Southern Bluefin Tunamengalokasikan kuota penangkapan SBT bagi masing-masing negara anggota dan cooperating non-members (CNMs)berdasarkan pada kriteria yang telah disepakati dan diatur oleh Komisi.

Upaya pengelolaan dan konservasi sumber daya SBT sangat diperlukan untuk menjaga keberlangsungan industri perikanan SBT di Indonesia. Upaya pengelolaan dan konservasi tersebut harus diperkuatdengan data ilmiah yang baik dan akurat. Kajian penting terkait hal tersebut adalah mengenai pengkajian stock. Beberapa informasi dan data yang diperlukan dalam pengkajian stockantara lain data mengenai: ukuran,musim penangkapan,komposisi hasil tangkapan, dan tingkat produktivitas perikanan tuna long line.Oleh karena itu, penelitian ini bertujuan untuk menghitungkomposisi hasil tangkapan dantingkat produktivitas armada tuna long lineyang menangkap SBT, mengestimasi musim penangkapan SBT, dan menghitung ukuran rata-rata tertangkap SBThasil tangkapan tuna long lineIndonesia. Hasil penelitian ini diharapkan dapatdijadikan sebagai bahan argumentasi Indonesia dalam pengaturan kuota penangkapan SBT oleh CCSBT.

\section{METODOLOGI}

\subsection{Waktu dan Tempat Penelitian}

Penelitian ini dilaksanakan pada bulan November 2012sampai Juli 2013 di dua tempat, yakni di Jakarta dan Pelabuhan Umum Benoa Bali. Pemilihan lokasi penelitian dilakukan dengan pertimbangan bahwa hasil tangkapan SBT di Indonesia sebagian besar didaratkan di Pelabuhan Benoa Bali dan pemangku kebijakan yang berada di Jakarta.

\subsection{Metode Pengumpulan Data}

Metode yang digunakan dalam penelitian ini adalah metode survei dengan analisis deskriptif dan menghitung komposisi hasil tangkapan, produktivitas, serta ukuran rata-rata tertangkap SBT. Data yang dikumpulkan adalah data sekunder dan primer. Data yang diperoleh diolah untuk mencapai tujuan dari penelitian ini.

Data yang dikumpulkan meliputiCatch Documentation Scheme (CDS) ta-hun 2010-2013, hasil tangkapan tuna long lineATLI tahun 2005-2012, hasil tangkapan tuna long linedari PT. Per-ikanan Samodra Besar (PSB) tahun 1990-2000 dan hasil wawancara dengan pihak terkait. Responden terdiri dari tiga asosiasi yaitu ATLI, ASTUIN dan ASPER-TADU (Asosiasi Perikanan Tangkap Ter-padu), perusahaan perikanan tuna, Di-rektorat Sumberdaya Ikan (Dit. SDI) - Direktorat Jenderal Perikanan Tangkap (DJPT), petugas Pelabuhan Perikanan Nusantara (PPN) Pengambengan, petu-gas enumerator Statistik Perikanan Dit. SDIDJPT, Loka Penelitian Perikanan Tuna (LPPT) BenoaBadan Penelitian dan Pengembangan Kelautan dan Perikanan (Balitbang KP)dan observer LPPT Benoa. Selain data tersebutjuga dikumpulkan data dari studi pustaka dan dokumentasi terkait dengan pemanfaatan perikanan tuna sirip biru selatan. 


\subsection{Analisis Data}

1. Analisis Komposisi Hasil Tangkapan

Komposisi hasil tangkapan tuna long lineIndonesia yang menangkap SBT dianalisis secara deskriptif. Hasil analisis disajikan secara naratif, diagram lingkar, dan grafik.

\section{Analisis Produktivitas Unit Penang- kapan Ikan}

Nilai produktivitas suatu unit penangkapan ikan akan menentukan tingkat efektivitas dan efisiensi unit penangkapan tersebut selama proses penangkapan di laut. Analisis yang dilakukan dalam tulisan ini bertujuan untuk mengetahui efektivitas daya tangkap tuna long lineIndonesia yang menangkap SBT dengan melihat tren nilai produktivitas selama beberapa tahun. Untuk mengetahui nilai produktivitas ini dapat dianalisis dengan menggunakan perhitungan nilai catch per unit effort (CPUE).Dalam penelitian ini data catch adalah hasil tangkapan SBT yang didaratkan dari kapal tuna long line (unit) yang merupakan upaya penangkapan (effort)(Gulland, 1991danAstuti, 2005). Berikut rumus yang digunakan dalam penelitian:

$$
\text { CPUE }=\frac{C_{t}}{E_{t}}
$$

dimana: $\mathrm{C}_{\mathrm{t}}=$ hasil tangkapan pada tahun ke- $t$ (ton)

$E_{\mathrm{t}}=$ upaya penangkapan pada tahun ke-t (unit)

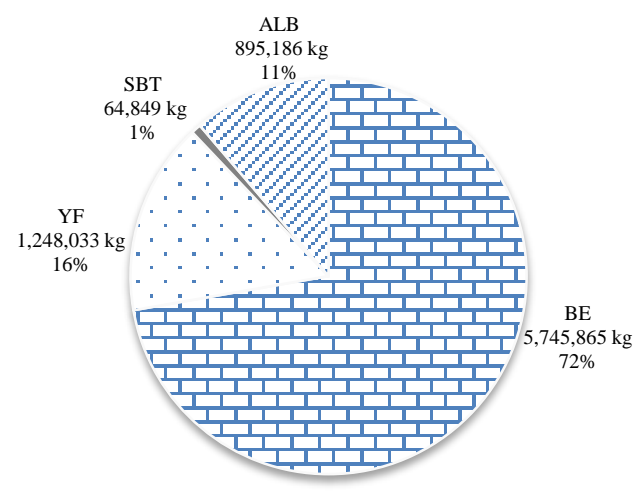

(a)

\section{Analisis Pendugaan Musim Penang- kapan \\ Menurut Uktolseja (1993) secara} sederhana musim ikan dalam setiap tahun adalah periode (bulan) pada saat hasil tangkapan lebih besar dari ratarata hasil tangkapan bulanan selama periode tahun tersebut.Musim penangkapan SBT dianalisis secara deskriptif dan hasil analisis disajikan secara naratif dan grafik.

\section{Analisis Ukuran Rata-rata Tertang- $\operatorname{kap}\left(\mathbf{L}_{\mathbf{5 0} \%}\right.$ )}

Menurut Saputra et al (2008), metode penentuan ukuran ikan rata-rata tertangkap dapat dilakukan mengunakan metode kurva logistik baku, yaitu dengan memplotkan presentase frekuensi kumulatif ukuran panjang.

\section{HASIL DAN PEMBAHASAN}

\subsection{Komposisi Hasil Tangkapan Tuna Long line}

Ikan tuna sirip biru selatan yang didaratkan di Indonesia selama ini tercatat tertangkap dengan menggunakan alat tangkap tuna long line. Rata-rata hasil tangkapan utama tuna long lineIndonesia adalah kelompok ikan tuna seperti madidihang atau tuna sirip kuning (yellowfin tuna; Thunnus albacares), tuna mata besar (bigeye tuna; Thunnus obesus), albakora (albacore; Thunnus alalunga), dan tuna sirip biru selatan (southern bluefin tuna; Thunnus macoyil).Komposisihasil tangkapantuna long linedisajikan pada Gambar 1di bawah ini.

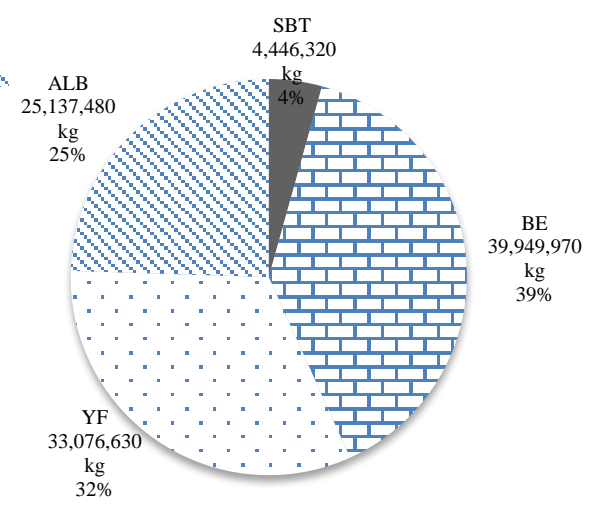

(b)

Keterangan : $\mathrm{BE}=$ bigeye tuna (tuna mata besar), $\mathrm{YF}=$ yellowfin tuna (tuna sirip kuning), SBT = southern bluefin tuna(tuna sirip biru selatan), ALB = albacore (albakora) 
Gambar 1. Komposisi hasil tangkapan tuna long linemilik (a) PT. PSB tahun 19902000, (b) ATLI tahun 2005-2012

Berdasarkan data hasil tangkapan tuna long linepada Gambar 1 dapat diketahui bahwa rata-rata hasil tangkapan tuna long lineterbesar adalah bigeye tuna. Rata-rata hasil tangkapan tuna long lineterkecil adalah southern bluefin tunasebesar 1 persendan 4 persen. Hasil penelitian Prisantoso et al (2010) memperoleh jenis tuna yang mendominasi hasil tangkapan kapal rawai tuna atau tuna long linedi Samudera Hindia adalah yellowfin tuna sedangkan SBT merupakan hasil tangkapan terkecil.Hasil tangkapan SBT yang memiliki rata-rata terkecil dari hasil tangkapan tuna lainnya. Sehingga dapat menyebabkan SBT dianggap sebagai hasil tangkapan sampingan (by-catch). Nilai ekonomi yang tinggi kemudian menjadikan SBT sebagai hasil tangkapan tambahan (by-product) dari industri perikanan tuna di Indonesia secara keseluruhan. Namun demikian, tren kontribusi SBT terhadap total produksi tuna dari tahun ke tahun meningkat (Gambar 2).

\subsection{Produktivitas Tuna Long line}

Produktivitas tuna long linemerupakan kemampuan kapal tuna long lineuntuk memperoleh hasil tangkapan SBT per tahun. Tinggi rendahnya nilai pro-duktivitas tuna long lineakan mencer-minkan tingkat efisiensi dan efektivitas dari unit penangkapan tuna long lineselama pada proses penangkapantuna berlangsung. Produktivitas kapal tuna long linedihitung berdasarkan hasil tangkapan SBT per unit penangkapan (CPUE). Nilai CPUE yang lebih tinggi dapat mencerminkan tingkat efisiensi penggunaan effort yang lebih baik.(Fauzi, 2010dalam Noordiningroomet et al, 2012).Berdasarkan data yang diperoleh selama 4 tahun (2010-2013) perhitungan rata-ratacatch per unit effort (CPUE) di pelabuhan Benoa Bali dan Pelabuhan Perikanan Samudera Nizam Zachman Jakarta adalah sebesar 4.40ton/unit setiap tahunnya. Rata-rata hasil tangkapan per satuan upaya penangkapan periode 2010-2013 secara umum mengalami peningkatan (Gambar 3). Hal ini menggambarkan bahwa tingkat kemampuan tuna long lineIndonesia untuk menangkap SBT dapat dikatakan baik seiring dengan mening-katnya produktivitas dalam tiga tahun terakhir dan persentase produksi SBT selama periode 19 tahun.

\subsection{Pendugaan Musim Penangkapan}

Ikan SBT tertangkap oleh kapal tuna long line Indonesia secara musiman. Sifat musiman SBT ditunjukkan oleh rata-rata bulanan hasil tangkapan SBT dalam kurun waktu 1991-2002 dan 2010-2012 (Gambar 4).

Gambar 4a menunjukkan bahwa musim penangkapan SBT berdasarkan hasil tangkapan bulanan SBT tahun 1991-2002 dimulai pada bulan September-April. Sementara, berdasarkan data tiga tahun terakhir (2010-2012), terjadi upaya penangkapan yang intensif karena dipacu oleh harga ikan yang tinggi. Upaya penangkapan SBT pada bulan Mei-Agustus yang dulunya jarang dilakukan sekarang banyak dilakukan sehingga pada bulan tersebut tetap mendapat SBT. Namun demikian, musim penangkapan SBT dimulai pada bulan Juli-April (Gambar 4b).

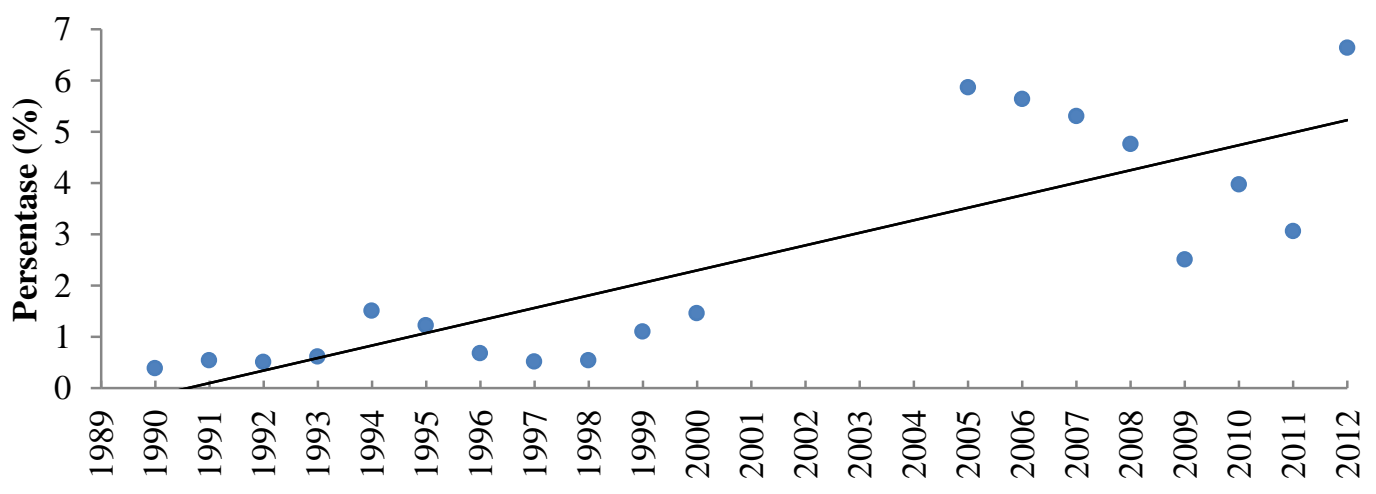

Tahun

Sumber : PT. PSB dan ATLI Bali, olah 
Gambar 2. Tren persentase produksi SBT Indonesia tahun 1990-2000 dan 2005-2012

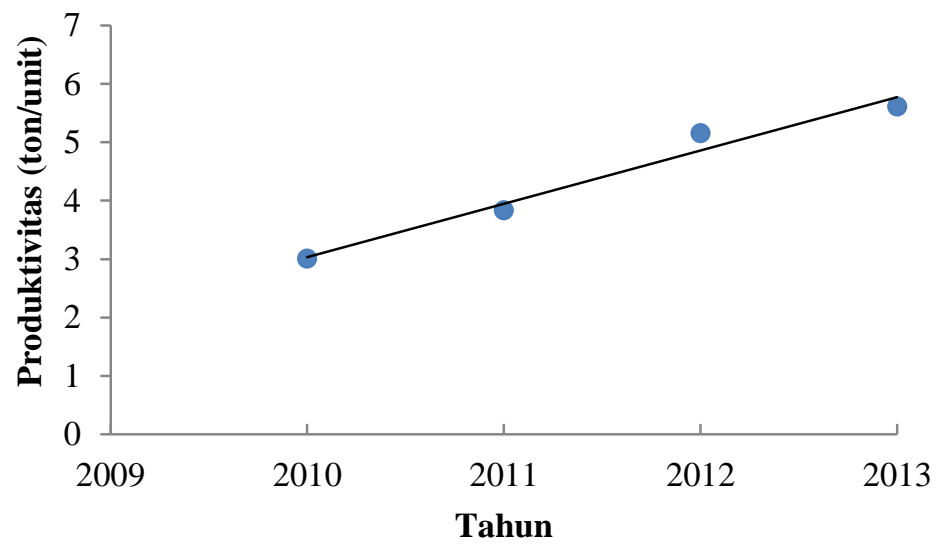

Sumber : CDS 2010-2013, olah

Data Tahun 2013 merupakan angka sementara per Juni 2013

Gambar 3. Tren produktivitas SBT kapal tuna long linetahun 2010-2013

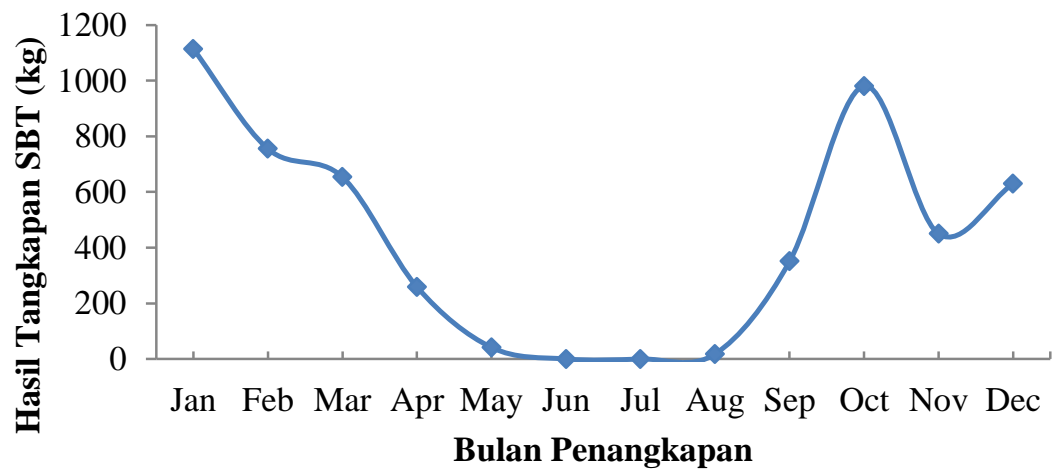

(a)

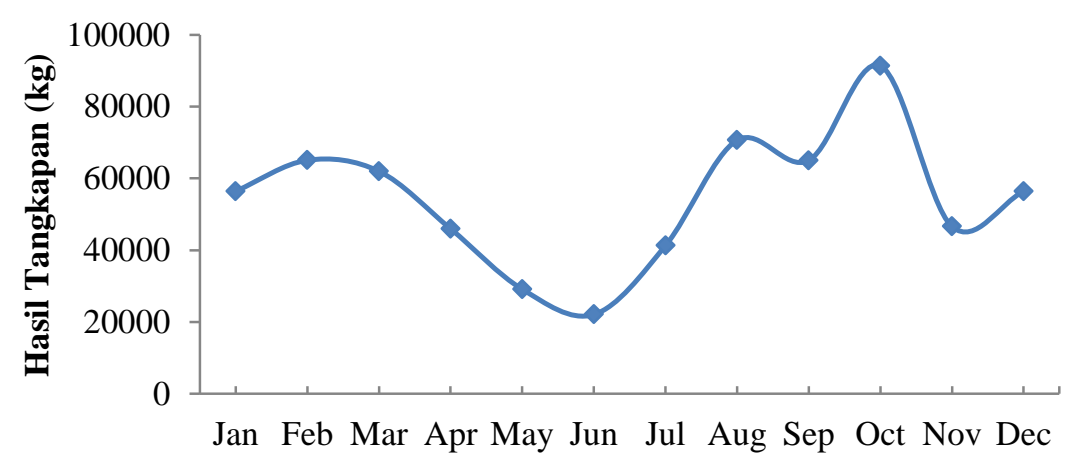

Bulan Penangkapan

(b)

Catatan: Data CDS Tahun 2012 merupakan angka sementara

Gambar 4. Rata-rata hasil tangkapan bulanan SBT berdasarkan (a) PT. PSB tahun 1991-2002, (b) CDS tahun 2010-2012 


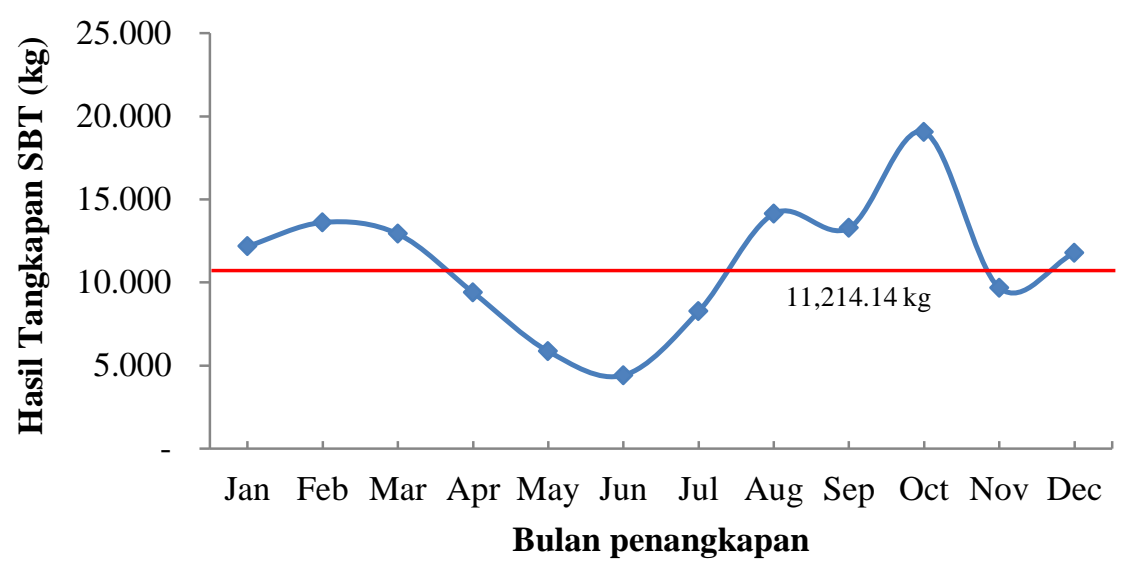

Sumber : PT. PSB dan CDS

Gambar 5. Rata-rata hasil tangkapan bulanan SBT tahun 1991-2002 dan 2010-2012

Musim penangkapan SBT berdasarkan data hasil tangkapan bulanan SBT dari tahun 1991-2002 dan 2010-2012 secara keseluruhanberlangsung dari bulan Agustus-Maretdan menurun pada bulan April-Juli. Puncak musim yang tertinggi terdapat dalam bulan Oktober (Gambar 5). Penentuan musim penangkapan ini didasarkan kepada nilai hasil tangkapan yang lebih besar dari rata-rata hasil tangkapan bulanan selama 15 periode sebesar $11,214.14 \mathrm{~kg}$.

Menurut National Report Indonesia Southern Bluefin Tuna Fisheries(2011) musim penangkapan SBT jika dilihat dari rata-rata hook rate per bulan terjadi pada bulan Agustus-April. Puncak tertinggi hook rate SBT terjadi pada bulan Oktober dan November berkisar antara 0.1 sampai 0.3 per 1000 mata pancing. Sedangkan hook rate terendah diperoleh pada bulan April-Agustus berkisar 0 sampai 0.01 per 1000 mata pancing. Sementara, sumber daya SBT diduga mempunyai tempat pemijahan (spawning ground) tunggal yaitu antara barat laut Australia dan perairan selatan pulau Jawa (Proctor et al, 1995; Yukinawa, 1987).

Menurut Farley dan Davis (1998) menyebutkan bahwa SBT yang berasal dari Samudera Hindia memijah dari bulan Oktober sampai Februari. Berdasarkan hasil penelitian Andamari et al(2005 dalam Mahrus 2012) disimpulkan bahwa pemijahan SBT berlangsung dari bulan September-April yang ditandai dengan banyaknya hasil tangkapan SBT oleh nelayan Indonesia. Penelitian yang sama juga menyimpulkan bahwa per-airan selatan Jawa dan Bali di Samudera Hindia pada akhir musim timur sampai awal musim barat (periode Agustus sampai Desember) merupakan musim penangkapan yang paling penting bagi perikanan SBT di Indonesia. Dengan de-mikian dapat dikatakan bahwa musim penangkapan SBT di Indonesia adalah bersamaan dengan pemijahan SBT. Jadi, dalam pemanfaatan SBT perlu adanya kehati-hatian dalam melakukan aktivitas penangkapan SBT untuk menghindari tertangkapnya baby tuna sirip biru selatan.

\subsection{Ukuran Rata-rata Tertangkap ( $\left.\mathrm{L}_{50} \%\right)$}

Hasil penelitian SBT yang didaratkan oleh kapal tuna long lineIndonesia berdasarkan data CDS tahun 2010-2012 dapat dilihat pada Gambar 6 berikut ini. 

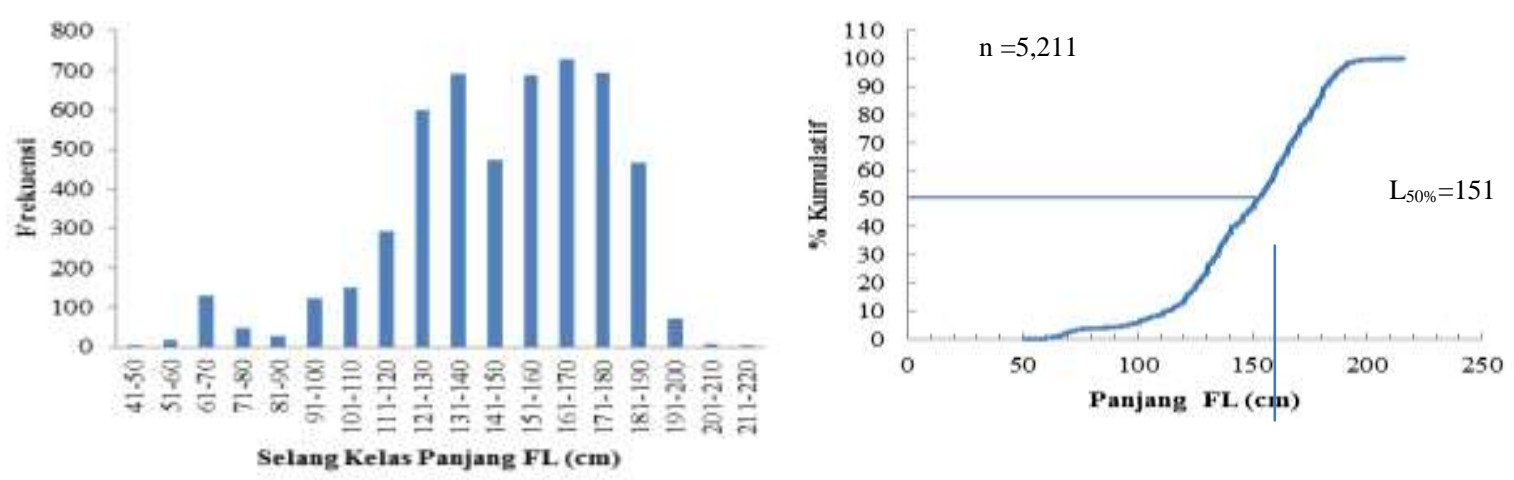

(a)
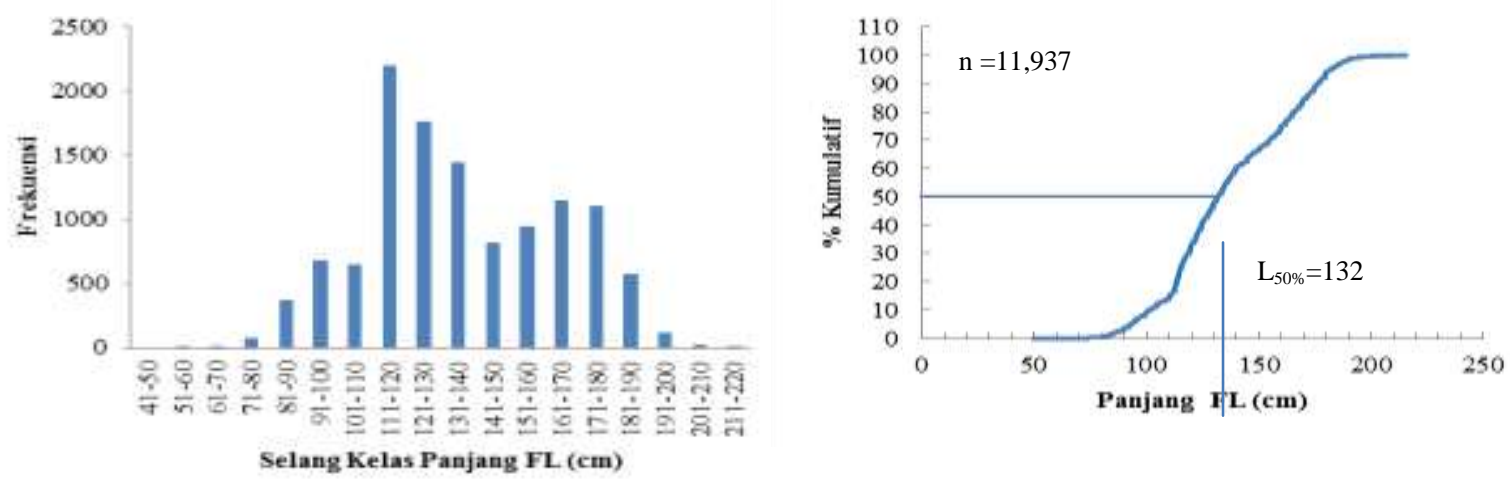

(b)
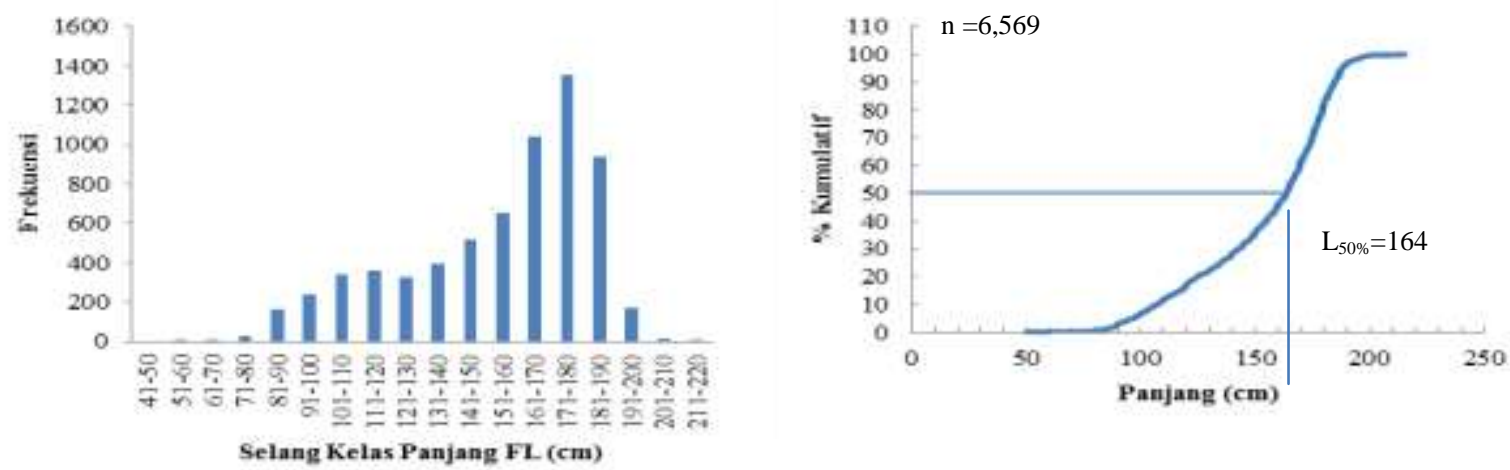

(c)
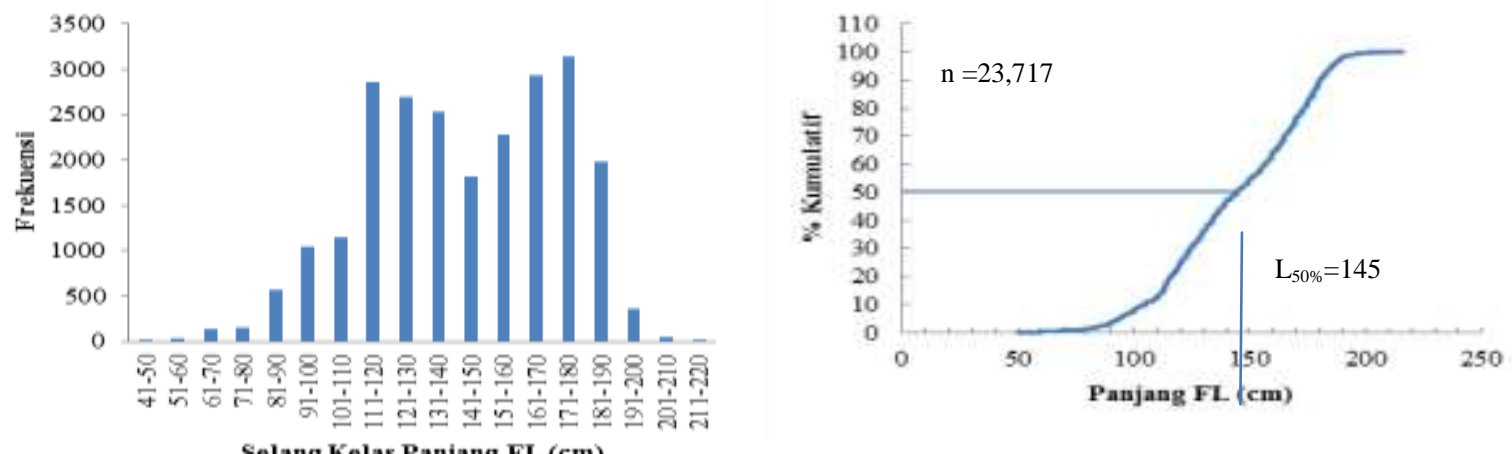

(d)

Gambar 6. Struktur ukuran dan ukuran rata-rata tertangkap SBT (a) Tahun 2010, (b) Tahun 2011, (c) Tahun 2012, (d) Tahun 2010-2012 
Tuna sirip biru selatan yang didaratkan di Indonesia selama tahun 20102012 memiliki distribusi frekuensi panjang berfluktuatif yang didominasi oleh panjang fork length (FL) pada kisaran $161-170 \mathrm{~cm}, 111-120 \mathrm{~cm}$ dan 171-180 $\mathrm{cm}$. Ukuran panjang rata-rata tertangkap SBT $\left(\mathrm{L}_{50 \%}\right)$ adalah $151 \mathrm{~cm}, 132 \mathrm{~cm}$ dan $164 \mathrm{~cm}$. Rata-rata distribusi frekuensi panjang SBT tahun 2010-2012 didominasi oleh panjang FL kisaran 171-180 cm dengan $\mathrm{L}_{50 \%}$ adalah $145 \mathrm{cmFL}$ (Gambar 6).

Ukuran ikan layak tangkap adalah ukuran ikan yang lebih besar dari ukuran panjang ikan saat pertama kali matang gonad (length at first maturity $=\mathrm{L}_{\mathrm{m}}$ ). Menurut Robins JP. (1963) menyatakan bahwanilai $\mathrm{L}_{\mathrm{m}}$ ikan SBT adalah $119 \mathrm{~cm}$. Sedangkan menurut Shingu (1970), Warashina dan Hisada (1970), Collette dan Nauen (1983) bahwa panjang pertama kali kematangan gonad atau $\mathrm{L}_{\mathrm{m}}$ ikan SBT diperkirakan pada ukuran 130 $\mathrm{cm}$ atau setara dengan berat sekitar 40 $\mathrm{kg}$.

Length at first maturity $\left(\mathrm{L}_{\mathrm{m}}\right)$ digunakan sebagai batasan minimal dalam mengeksploitasi sumberdaya ikan. Berdasarkan hal tersebut maka panjang rata-rata tertangkap seharusnya tidak boleh lebih kecil dari $\mathrm{L}_{\mathrm{m}}=119 \mathrm{~cm}$ atau
$\mathrm{L}_{\mathrm{m}}=130 \mathrm{~cm}$. Hasil perhitungan diperoleh bahwa ukuran rata-rata tertangkap SBT pertama kali $\left(\mathrm{L}_{50 \%}\right)$ lebih besar dari $\mathrm{L}_{\mathrm{m}}$. Rata-rata persentase hasil tangkapan SBT yang mempunyai panjang $\mathrm{FL}>$ $\mathrm{L}_{\mathrm{m}}=119 \mathrm{~cm}$ dan $\mathrm{FL}>\mathrm{L}_{\mathrm{m}}=130 \mathrm{~cm}$ adalah sebesar 78.43 persendan 65.87 persen (Tabel 1). Menurut penelitian Mahrus (2012) distribusi frekuensi ukuran panjang ikan SBT terbanyak pada fork length antara 171-180 cm. Panjang pertama kali tertangkap (length at first capture $/ \mathrm{L}_{\mathrm{c}}$ ) ikan SBT selama penelitian adalah berukuran $158.2 \mathrm{~cm}$ yang diduga ukuran tersebut telah melewati masa ikan melakukan pemijahan (spawning). Hal ini mengasumsikan bahwa dari sisi peluang reproduksi masih terjamin dan dari tingkat pemanfaatan SBT masih belum menunjukan indikasi berlebih (under-exploited).

Rata-rata distribusi frekuensi panjang SBT bulanan dengan nilai $\mathrm{FL}>$ $\mathrm{L}_{\mathrm{m}}=119 \mathrm{~cm}$ dan $\mathrm{FL}>\mathrm{L}_{\mathrm{m}}=130 \mathrm{~cm}$ banyak tertangkap pada bulan Agustus-Maret. Bulan tersebut sama dengan hasil pendugaan musim penangkapan SBT yang terjadi pada bulan Agustus-Maret (Gambar 7). Hal ini menunjukkan bahwa pada bulan-bulan tersebut ikan SBT telah layak tangkap.

Tabel 1.Persentase distribusi fork length SBT tahun 2010-2012

\begin{tabular}{|c|c|c|c|c|c|c|c|}
\hline \multirow{3}{*}{$\begin{array}{c}\text { Ukuran } \\
\text { Fork length }(\mathrm{cm})\end{array}$} & \multicolumn{7}{|c|}{ Jumlah } \\
\hline & \multicolumn{3}{|c|}{2010} & \multirow{2}{*}{$\begin{array}{r}2011 \\
(\%) \\
\end{array}$} & \multirow[b]{2}{*}{ (ekor) } & \multirow{2}{*}{$\begin{array}{r}2012 \\
(\%) \\
\end{array}$} & \multirow{2}{*}{$\begin{array}{c}\text { Rata-rata } \\
(\%)\end{array}$} \\
\hline & (ekor) & $(\%)$ & (ekor) & & & & \\
\hline \multicolumn{8}{|l|}{ Robin J.P (1963) } \\
\hline$\leq \mathrm{L}_{\mathrm{m}}=119 \mathrm{~cm}$ & 682 & 13.09 & 3667 & 35.58 & 1053 & 16.03 & 21.57 \\
\hline$>\mathrm{L}_{\mathrm{m}}=119 \mathrm{~cm}$ & 4529 & 86.91 & 6639 & 64.42 & 5516 & 83.97 & 78.43 \\
\hline TOTAL & 5211 & 100 & 10306 & 100 & 6569 & 100 & 100 \\
\hline \multicolumn{8}{|c|}{ Shingu (1970), Warashina and Hisada (1970), Collette \& Nauen (1983) } \\
\hline$\leq \mathrm{L}_{\mathrm{m}}=130 \mathrm{~cm}$ & 1391 & 26.69 & 5480 & 53.17 & 1479 & 22.51 & 34.13 \\
\hline$>\mathrm{L}_{\mathrm{m}}=130 \mathrm{~cm}$ & 3820 & 73.31 & 4826 & 46.82 & 5090 & 77.49 & 65.87 \\
\hline TOTAL & 5211 & 100 & 10306 & 100 & 6569 & 100 & 100 \\
\hline
\end{tabular}




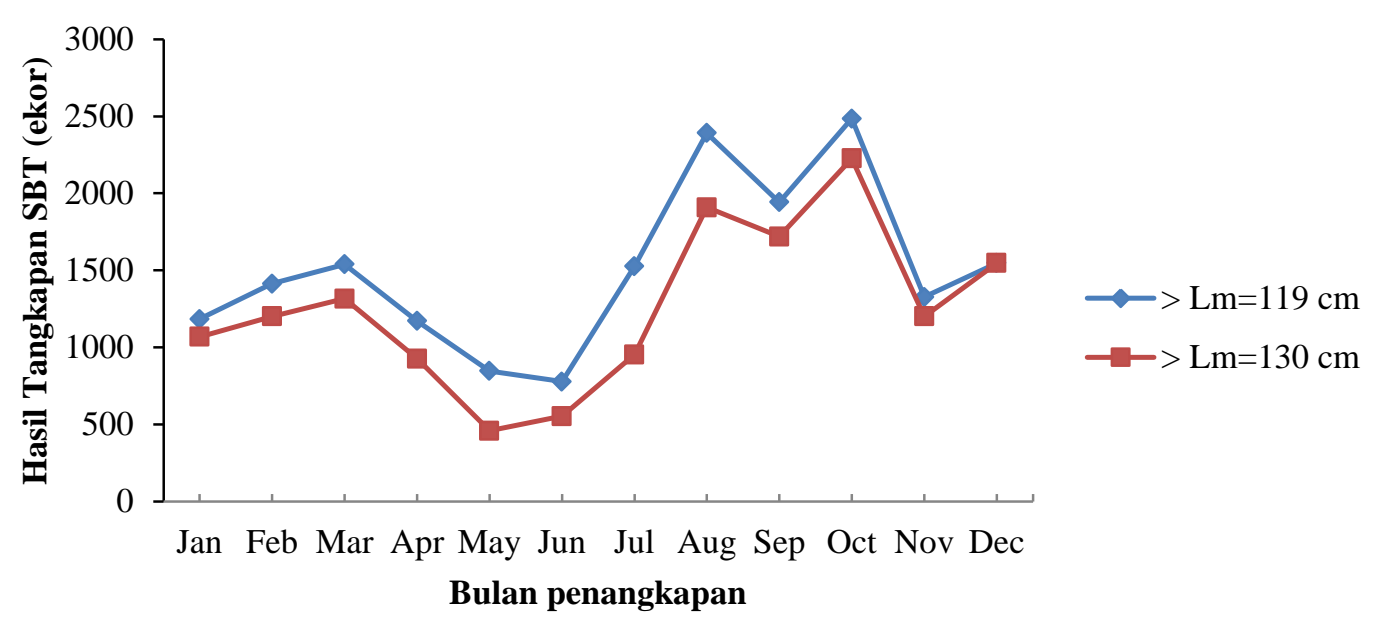

Gambar 7.Distribusi frekuensi panjang SBT bulanan tahun 2010 - 2012

\section{KESIMPULAN DAN SARAN}

\subsection{Kesimpulan}

1. Southern bluefin tuna memiliki nilai persentase terkecil sebesar 4 persendari komposisi hasil tangkapan tuna long linedi Indonesia.Tren persentase produksi SBT memiliki kecenderungan meningkat dari tahun ke tahunseiring dengan meningkatnya tren nilai - tuna long lineyang menangkap SBT. Hal ini berarti bahwa tingkat kemampuan efektivitas tuna long lineIndonesia dapat dikatakan masih tergolong baik.

2. Berdasarkan analisis rata-rata hasil tangkapan bulanan SBT didugamusim penangkapan SBT di Indonesia dimulai pada bulan Agustus-Maret.

3. Ukuran rata-rata tertangkap SBT $\left(\mathrm{L}_{50 \%}\right)$ yang didaratkan di Indonesia adalah berukuran $145 \mathrm{~cm}$ FL yang lebih besar dari length at first maturity $\left(\mathrm{L}_{\mathrm{m}}\right)$.

\subsection{Saran}

1. Perlu adanya pengaturan bulan penangkapan SBT untuk efisiensi waktu dan kelestarian sumber daya SBT itu sendiri.

2. Perlu adanya penelitian lebih lanjutmengenai tingkat kematangan gonad (TKG) untuk SBT yang tertangkap pada musim penangkapan.

3. Perlu perbaikan sistem pengelolaan kuota penangkapan SBT di Indonesia.

\section{DAFTAR PUSTAKA}

Astuti EM. 2005. Dimensi Unit Penangkapan Pukat Udang dan Tingkat Pemanfaatan Sumberdaya Udang di Perairan Laut Arafura. [skripsi]. Bogor (ID): Institut Pertanian Bogor.

Collette BB, Nauen CE. 1983. FAO Species Catalogue. Vol. 2. Scombrids of the world. An Annotated and Mlustrated Catalogue of Tunas, Mackerels, Bonitos and Related Species Known to Date. FAO Fish. Synop. 125 (2):137p. Rome: FAO.

Farley JH, Davis TLO. 1998. Reproductive Dynamics of Southern Bluefin Tuna, Thunnus maccoyii. Fishery Bulletin. 96(2):223-236.

Gulland JA. 1991. Fish Stock Assessment: A Manual of Basic Methods. Rome: Food and Agricultural Organization of The United Nations.

Mahrus. 2012. Distribusi Ukuran Panjang dan Berat Tuna Sirip Biru Selatan (Thunnus macoyii Castelnau, 1872) Yang Tertangkap Dari Perairan Samudera Hindia dan Didaratkan di Pelabuhan Benoa Bali [tesis]. Depok (ID): Universitas Indonesia.

Noordiningroom $R$, Anna $Z$, Suryana AAH. 2012. Analisis Bioekonomi Model Gordon-Schaefer Studi Kasus Ikan Nila (Oreochromis niloticus) di perairan Umum Waduk Cirata Kabupaten Cianjur Jawa Barat. Jurnal Perikanan dan Kelautan. 3(3):263-274.

Prisantoso BI, Widodo AA, Mahiswara, Sadiyah L. 2010. Beberapa Jenis Hasil Tangkap Sampingan (bycatch) 
Kapal Rawai tuna di Samu-dera Hindia Berbasis di Cilacap. Jurnal Penelitian Perikanan Indo-nesia. 16(3):173-258.

Proctor CH, Thresher RE, Gunn JS, Mills DJ, Harrowfield IR, Sie SH. 1995. Stock Structure of The Southern Bluefin Tuna Thunnus maccoyii: An Investigation Based on Probe Microanalysis of Otolith Composition. Marine Biology. 122:511-526.

Robins JP. 1963. Synopsis of The Biological Data on Bluefin TunaThunnus thynnus maccoyii (Castelnau) 1872. FAO Fish. Rep. 2(6):562-587.

Saputra SW, Rudiyanti S, Mahardhini A. 2008. Evaluasi Tingkat Eksploitasi Sumberdaya Ikan Gulamah (Johnius $s p$ ) Berdasarkan Data TPI PPS Cilacap. Jurnak Saintek Perikanan. 4(1):56-61.

Shingu C. 1970. Studies Relevant to Distribution and Migration of The Southern Bluefin Tuna. Bulletin of Far Seas Fisheries Research Laboratory. 3:57-113.

Uktolseja JCB. 1993. Status Perikanan Ikan Pelagis Kecil dan Kemungkinan Pemanfaatannya sebagai Ikan Umpan Hidup untuk Perikanan Rawai Tuna di Prigi, Jawa Timur. Jurnal Penelitian Perikanan Laut. 80:18-45.

Warashina I, Hisada K. 1970. Spawning Activity and Discoloration of Meat and Loss of Weight in The Southern Bluefin Tuna. Bulletin of Far Seas Fisheries Research Laboratory. 3:147-165

Yukinawa M. 1987. Report on 1986 Research Cruise of The $R / V$ Shoyo Maru. Distribution of Tuna and Billfishes Larvae and Oceanographic Observation in The Eastern Indian Ocean January - March, 1987. Rep. Res. Div. Fish. Agency Jpn. 61:1-100. 